\title{
Unresolved Water Conflicts by Water Sector Institutions in Ewaso Ng'iro North River Sub-Basin, Kenya
}

\author{
*LESRIMA, S; NYAMASYO, G; KIEMO, K \\ Wangari Maathai Institute for Peace and Environmental Studies, University of Nairobi, Kenya \\ P.O. Box 30197 - 00100 GPO Nairobi, Kenya \\ *Corresponding Author. Email: simeonlesrima@gmail.com
}

\begin{abstract}
Water conflicts have huge impacts on livelihoods and without proper redress, have capacity to stall economic development of a community. This paper therefore explicates the impacts of unresolved water related conflicts in Ewaso Ng'iro North River sub-basin in Kenya and their persistence despite past major institutional and policy reforms in the water sector. Repetitive unresolved water conflicts curtail the prosperity of the communities on river basins. Study objective was to assess continued unresolved conflicts albeit the numerous and robust water reforms. Mixed methods research design was adopted to capture both primary and secondary data. Game Theory supported the study explicating how water users both upstream and downstream are players whose payoffs if not transparent cause conflicts. Sampling formula was utilized to derive a sample size of 384 respondents and employed simple random sampling. Primary data were collected through structured questionnaires, Key Informant interviews, Focused Group Discussions and Transect walks. Results show that water users aware of regulations in place governing water on river basins however had weak compliance. The legal and policy reforms need to be up scaled to enhance capacity to resolve conflicts by WRUAs and WRA. Compliance to regulations governing water to be enforced by mandated institutions to curb the repetitiveness of unresolved water conflicts.
\end{abstract}

\section{DOI: https://dx.doi.org/10.4314/jasem.v25i2.21}

Copyright: Copyright $\odot 2021$ Lesrima et al. This is an open access article distributed under the Creative Commons Attribution License (CCL), which permits unrestricted use, distribution, and reproduction in any medium, provided the original work is properly cited.

Dates: Received: 12 December 2020; Revised: 26 January 2021; Accepted: 12 February 2021

Keywords: Ewaso Ng'iro, Institutional reforms, Water Resources, Water Users, Unresolved Conflicts.

Trans-boundary river basins presents a bone of contention among their riparian states users and breeds simmering conflicts on water resources (Munia et al., 2016; Rahman, 2013). An ever increasing demand for water challenged by its scarcity raise the risk of violence with pronounced impacts on the downstream and upstream landscapes (Bernauer and Böhmelt, 2020; Okpara et al., 2015). Notably, Kenya is ranked as water scarce country with its per capita water availability at 650 cubic meters below the threshold of recommended international meters of $1700 \mathrm{cubic} / \mathrm{m}$ per capita /per year (Kiteme, 2020; Munia et al., 2016). Water accessibility in Ewaso Ng'iro North River Basin portrays protracted periods of unresolved conflicts on the water resources with devastating impacts (Bernauer and Böhmelt, 2020; Didier et al., 2011; Habiyakare and Zhou, 2015). Over the past decades, the dry flow of the Ewaso Ng'iro has reduced by $90 \%$, consequently affecting downstream livelihoods and ecosystems (Habiyakare and Zhou, 2015; Kiteme, 2020; Kiteme et al., 2008; Lanari et al., 2018). The unreliability of rainfall in the region affects water volumes thereby a possible trigger to water conflicts over water access and availability (Kiteme, 2020; Kiteme and Gikonyo, 2002). Ewaso Ng'iro
North River sub basin underwent drastic socioeconomic transition from post-independence period highlighting pockets of unresolved water conflict (Habiyakare and Zhou, 2015; Lanari et al., 2018). The socio-economic transitions include large-scale ranching, migration of small-scale farmers and establishment of commercial large-scale horticultural farms from its original traditional pastoralists land use system (Baur et al., 2000; Munia et al., 2016). With sharp increase in population densities in addition to the changing land use systems, pressures on river water resources dramatically increases highlighting the potential of water related conflicts (Kiteme, 2020; Lanari et al., 2018; Roe et al., 2009). The complexities in competition for water resources affect its distribution and ownership. Stakeholder's perception of inequality in water allocation and consumption is seen as a trigger to latent conflicts over water access and availability (Bond, 2014; Daniell and Barreteau, 2014; Wang et al., 2017). Untamed competition for scarce water resources and marginalization of minorities, trigger use of violence to regain possession of lost rights or secure access to land (FAO and IWMI, 2018; Warurii, 2013). The unresolved water related conflicts have impacts that require strong institutional 
frameworks to resolve and prevent escalation of water conflicts (Daniel and Barreteau, 2015; Swain, 2011; Wheeler et al., 2018). Despite reforms in the water sector in Kenya, lacks of coordinated system for sustainable use of water resource is noted by all players in the sub-basin providing a basis for water related conflicts. Conflicts manifest in complaints over unauthorized, illegal and unequal water abstraction coupled with overlapping mandates of institutions in the water sector(Government of Kenya GOK, 2010; Lanari et al., 2018; Opiyo et al., 2012). Institutions such as Water Resources Management Authority (WMRA) became Water Recourses Authority (WRA) after delegating some management functions to Water Resource User's Associations (WRUAs) on catchment protection with fiscal support from Catchment Protection Committees (CPC) (Baur et al., 2000; Government of Kenya GOK, 2010; Nelson, 2010; Roe et al., 2009) thus making them play major mediation role in conflict prevention. Decentralization in policy and institutional arrangements were undertaken in realisation of the need to prevent and mitigate conflicts and create an enabling environment for implementation of Government development agendas (FAO and IWMI, 2018; Habiyakare and Zhou, 2015; Hui et al., 2016; Opiyo et al., 2012). This paper explicates the impacts of unresolved water related conflicts in Ewaso Ng'iro North River sub basin and their persistence despite past major reforms in institutions, polices in the water sector.

\section{MATERIALS AND METHODS}

Upper Ewaso Ng'iro North River Sub-Basin was the study area which is about $2,175 \mathrm{Km}^{2}$ situated within Nanyuki. Rivers in the study originate from the Mt. Kenya region and the Aberdare ranges. Upper Ewaso $\mathrm{Ng}$ 'iro is catchment area with a growing population and changed livelihoods (Kenya National Bureau of Statistics (KNBS), 2019). In the lower regions, pastoralism is the main economic activity while crop and dairy farming taking place within the humid regions on the slopes of Mt. Kenya including the Aberdares(Kiteme, 2020). Mixed methods research design was utilized in collecting the data (Creswell and Creswell, 2018). The target population was households from adjacent Sub-Counties of Buuri in Meru County, Kieni of Nyeri County, Laikipia East and Laikipia North of Laikipia County. Simple random sampling used to select a sample of 384 calculated using a formula for a large population recommended by (Williams, 2011). The study utilized both primary and secondary data. Primary data were collected through structured questionnaires, interviews, and focused group discussions with information using mobile software (Kvale and Brinkmann, 2015).

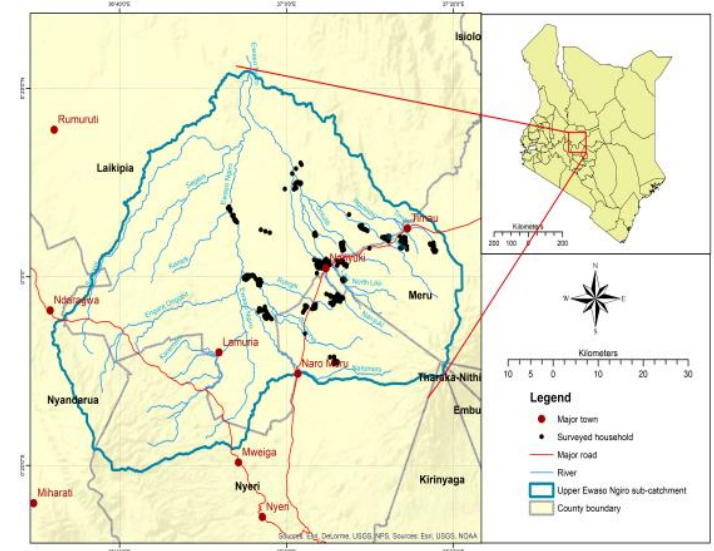

Fig 1: Study Area Map with Surveyed areas (adopted from Government of Kenya, Water Resources Authority 2016)

\section{RESULTS AND DISCUSSION}

Results in Table 1 illustrates that $59.4 \%$ of respondents agree existence of water related conflicts while $40.6 \%$ who disagreed while dry seasons are the times when water conflicts increase compared to wet seasons. The unresolved water conflicts are most prevalent along the rivers and wetlands and minimal in urban centers. Ethnic composition of Households interviewed were agro pastoralists and agriculturalists Kikuyu and Meru represented by $85.9 \%$ while the pastoralist were the Kalenjin, Turkana, Samburu and Maasai representing about $10 \%$ of the sample. Unresolved water conflicts are persistent among the agro-pastoralists and the pastoralists who are in search of water and pasture for their livestock.

Table 1: Repetitiveness of Unresolved Water conflicts in Ewaso

\begin{tabular}{|c|c|c|}
\hline $\begin{array}{l}\text { Repetitiveness of water } \\
\text { conflicts }\end{array}$ & Response & $\begin{array}{c}\text { Percent } \\
(\%)\end{array}$ \\
\hline \multirow[t]{3}{*}{ Water conflicts existence } & No & 40.6 \\
\hline & Yes & 59.4 \\
\hline & Total & 100 \\
\hline \multirow[t]{4}{*}{ Period of conflict prevalence } & wet seasons & 48.7 \\
\hline & Dry seasons & 51.3 \\
\hline & Total & 100 \\
\hline & Along the & \\
\hline \multirow{9}{*}{$\begin{array}{l}\text { Location Prevalence of } \\
\text { Unresolved conflicts }\end{array}$} & Rivers and & 234 \\
\hline & $\begin{array}{l}\text { Populated } \\
\text { areas such }\end{array}$ & \\
\hline & $\begin{array}{l}\text { Urban } \\
\text { centers }\end{array}$ & 11.2 \\
\hline & Semi-Arid & \\
\hline & $\begin{array}{l}\text { Areas } \\
\text { during dry }\end{array}$ & \\
\hline & seasons & 35.2 \\
\hline & $\begin{array}{l}\text { Rivers } \\
\text { downstream }\end{array}$ & 17.2 \\
\hline & centers & 13 \\
\hline & Total & 100 \\
\hline
\end{tabular}

Influence of Ethnic composition in Unresolved Water Conflicts in Ewaso Ng'iro, Laikipia County 
The respondents' perception of water conflict trends for the period of 1970 to 2015 in Figure 3 indicates a steady progression of water related conflicts with years 2008-2015 having the highest number of conflicts. The upward rise of unresolved water conflicts was perceived to be enhanced by weak implementation of water reforms and climate change effects such as droughts.

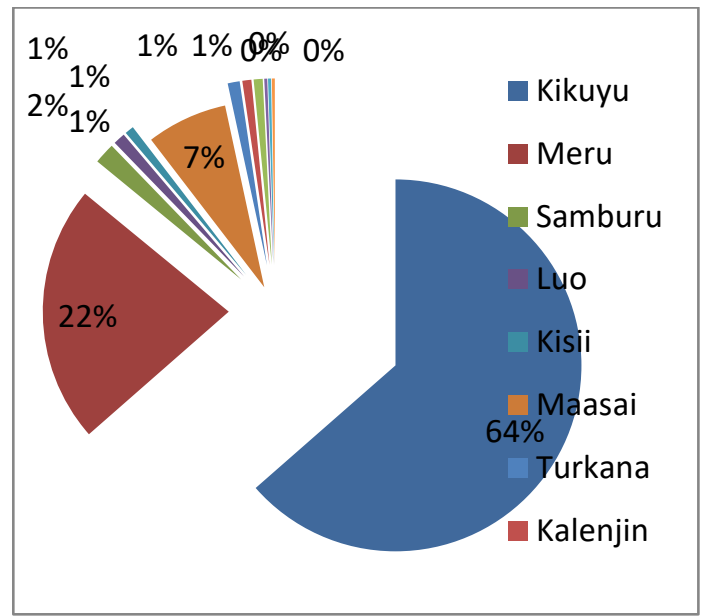

Fig 2: Influence of Ethnic composition in Unresolved Water Conflicts in Ewaso Ng'iro

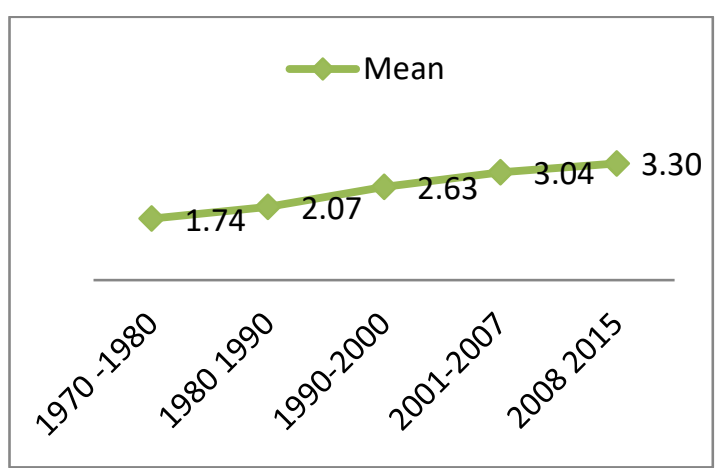

Fig 3: Respondents' Perception on Unresolved Water Conflicts in Ewaso Ng'iro

Results in Figure 4 illustrate the respondent's perception of repetitiveness of water conflict progress with a majority agreeing that conflicts have increased over time and are dynamic. Majority of the respondents agreed that repetitiveness of unresolved water conflicts would continue to rise due to population increase, infrastructural developments and environmental degradation. $54.2 \%$ of respondents perceived that institutions in the water sector have the capacity to resolve the conflicts unlike $39.4 \%$ who cited lack of proper water management and governance by institutions contributes to the repetitiveness and unresolved water conflicts.

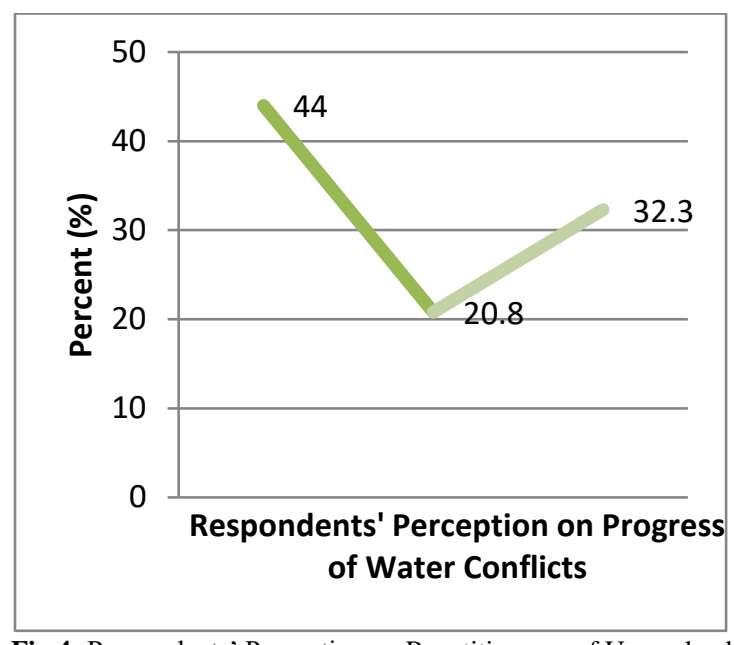

Fig 4: Respondents' Perception on Repetitiveness of Unresolved Water Conflicts Progress Ng'iro

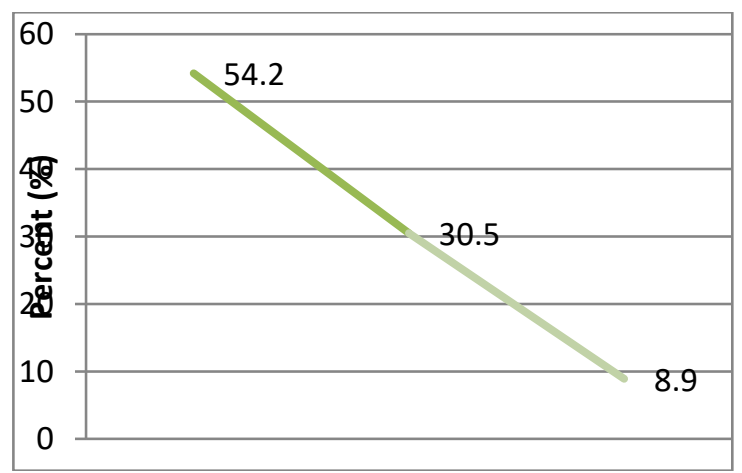

Fig 5: Perceived Institutional Capacity in Water Conflicts Resolution in Ewaso Ng'iro,

Unresolved Water Conflicts Resolution by Water Institutions in Ewaso Ng'iro: Management of water conflicts by institutions is illustrated by $43.5 \%$ of the respondents reporting conflicts to Provincial Administrations, $23.7 \%$ to faith-based organizations and $19.5 \%$ reported to Water Resources Users Associations.

Table 2: Unresolved Water Conflicts Resolution by Water Institutions in Ewaso Ng'iro

\begin{tabular}{lc}
\hline Water Conflicts Resolution Reported (Institutions) & Percent \\
\hline WRUA officials & 19.5 \\
Police/Security apparatus & 2.9 \\
Provincial administration & 43.5 \\
Faith based organizations & 23.7 \\
No reporting & 10.4 \\
Total & $\mathbf{1 0 0}$ \\
\hline
\end{tabular}


Table 3: Water Institutions with Unresolved Water Conflicts in Ewaso Ng'iro

\begin{tabular}{lllll}
\hline & & \multicolumn{3}{c}{ Existence of Unresolved Water Conflicts } \\
\hline Management of & No & Yes & Total \\
water Conflicts & WRUA officials & 19 & 36 & 55 \\
& Community Members & 41 & 17 & 58 \\
& NAWASCO & 53 & 88 & 141 \\
& Water Project committees & 42 & 88 & 130 \\
& Total & $\mathbf{1 5 5}$ & $\mathbf{2 2 9}$ & $\mathbf{3 8 4}$ \\
\hline
\end{tabular}

Results in Table 3 indicate that respondents agreed the existence of conflicts and the institutions they report conflicts on water with NAWASCO and Water project committees having the most cases of unresolved water conflicts. The data illustrates the presence of water related conflict in Upper Ewaso Ng'iro River Sub Basin in Kenya with various causes outlined explicating the unresolved conflicts (Kiteme, 2020; Lanari et al., 2018; Shao et al., 2017). Results agree with previous studies that rapidly increasing water demand as a result of rapid population growth; land use changes along rivers and wetlands have the potential to trigger repetitive conflicts (Daniel and Barreteau, 2015; Habiyakare and Zhou, 2015). Dynamics of the socio-economic landscapes on the basin elucidates the gaps that exist in the water sector despite numerous water sector reforms (Bernauer and Böhmelt, 2020; Okpara et al., 2015; UNESCO, 2018). This finding corroborates with those of (Isaboke, 2015) who posited that over-abstraction of water by large-scale farmers $90 \%$ of which is unauthorized among water users are responsible for reduced water volumes in the downstream increasing frequency of conflicts among water users (Shrestha et al., 2020, 2018). Water conflicts between the upstream and downstream users arise from over exploitation with increased abstractions upstream at the expense of the downstream water users (Kiteme, 2020). Similarly, (Munia et al., 2016) also pointed out that during the dry season, irrigation water demands and economic loss for not irrigating a water-stressed crop are highest thus uncontrolled abstractions. The study supports the perception that upstream water users impact negatively water access and availability for downstream users in most of the trans-boundary river basins (Baur et al., 2000; Bernauer and Böhmelt, 2020; Daniel and Barreteau, 2015; Nelson, 2010). This study agrees that upstream water users tend to generate more conflicts from their over abstraction practices and riparian degradation leading to water pollution as described by OLtulili, Ngushishi and Nanyuki WRUAs Focus Discussion Groups (FDG) and Key Informers Interviews (Broadmeadow and Nisbet, 2004; Funder et al., 2012; Kiteme, 2020). Although the presence of conflicts appears often to be over emphasized, this study, however, agrees with similar studies that scarcity acts as trigger to latent discontents during times of severe droughts coupled with political activity as experienced in the years; 1984, 1994,and 2015 (Bond, 2014; Kiteme et al., 2008). Despite the presence of institutions to govern water usage and accessibility, majority of the respondents laid blame on water scarcity to skewed administration of upstream water users (Chen and Olden, 2017; Okpara et al., 2015; Swain, 2011). The frequency of conflicts was noted especially in the months of January and February for their dry nature and reduction of water volumes in sub basin (Hui et al., 2016, MAHLAKENG, 2015; Yang and Cai, 2014). Similarly, results also agreed with (Lanari et al., 2018) that established that water conflicts were common during dry season and involved mainly pastoralists and large scale farmers followed by farmers upstream and downstream water users getting worse over the years. Transects visits to meet WRUAs as well as FGD mention that causes of conflicts include low flows in dry season, prolonged drought or lack of rains, ignorance by few members, illegal abstraction (Kiteme et al., 2008; Shrestha et al., 2018; Zhou et al., 2019). Perceptions by the respondents of unfair water provision suggest that Large-scale farms and hotels never lack water even during dry seasons while water rationing is imposed on less favoured water users by the main Water services providers such as Nanyuki Water and Sanitation Company (NAWASCO) thus exacerbating water related conflicts (Kiteme, 2020; Kiteme et al., 2008; Warurii, 2013). This suggests that participation in conflict resolution is still skewed towards government agency rather than devolved reformed institutions. Cooperation reduces the disputes among various users of shared resources is important in conflict prevention one entity should not be seen to be dominant in the game of since it breeds a sense of inequality and marginalisation(Hui et al., 2016; Jhawar et al., 2018; Nelson, 2010; Wheeler et al., 2018). This suggests that conflict resolution mechanisms and avenues remain unfocused and therefore weakens the capacity to deal with unresolved conflicts. Apart from competition among water users, persistent droughts, lack of strong institutions to manage equitable water use, political differences and biased property rights over access to land constitute other factors that have led to conflicts (Bond, 2014; Habiyakare and Zhou, 2015; Le Meur et al., 2006; 
Opiyo et al., 2012; Warurii, 2013). The data acknowledges the existence of other causes of water related conflicts such as latent conflicts over marginalization, political interference, corruption and ethnic profiling (Didier et al., 2011; Opiyo et al., 2012; Rahman, 2013). The findings show that $37 \%$ of the respondents point out that water related conflicts was arbitrated between the feuding parties, $20.1 \%$ sought legal redress, $15.6 \%$ sending warnings to rule breakers while $12.5 \%$ mention arrests of rule breakers. Using the game theory as explicated in Ostrom's principles of graduated punishment of water rules violators (Faghih and Akhavian, 2019; Ostrom, 2000; Rahman, 2013; Shao et al., 2017). The findings concur with (Muigua, 2014) who established that the current framework has not been efficacious in resolving conflicts and that there is a need to develop a new approach to conflict management. Action taken to solve water conflicts are graduated with arbitration being the most preferred method, reporting to the police and use of legal actions (Daniell and Barreteau, 2014; FAO and IWMI, 2018; Habiyakare and Zhou, 2015). Results show that water users tend to trust various institutions to handle water related conflicts. According to (Isaboke, 2015) conflicts over water resources further intensified by inability by the institutions mandated to manage the use of water resources and ensure equitable water use among all the waters users. Unreported and unexpressed conflicts of elite persons diverting river water at all seasons with impunity and without regard to downstream water users (Funder et al., 2012; Kiteme et al., 2008; Pandey, 2011). WRUAs manage projects NAWASCO and project committees managed water sources reported to experience fewer conflicts (Isaboke, 2015; Kiteme and Gikonyo, 2002; Lanari et al., 2018). Previous studies suggest that WRUA's capacity through catchment committees will build another bureaucratic layer below WRA thereby inability to resolve conflicts (Lanari et al., 2018). It is suggested that it is more effective to involve counties in catchment protection and in financing institutions supervising implementation of reforms (Lanari et al., 2018; Petersen-Perlman et al., 2017; UNESCO, 2018). This finding is also supported by studies on applicability of game theory in selected rivers in Upper Ewaso Ng'iro North river basin (Dinar and Hogarth, 2015; Faghih and Akhavian, 2019; Gichuki, 2010; Habiyakare and Zhou, 2015). Delayed operationalization of Catchment Basin Protection Committees to support WRUAs as provided in the Water Act 2016 coupled with and ineffective institutions responsible for management of water resources perpetuates unresolved conflicts.
Conclusion: Water scarcity and water stress from high water demand, population increase and climate change remain a basis for repetitive unresolved conflicts within the Upper Ewaso Ng'iro North River Subbasin. Water related conflicts increase due to poor governance by institutions whose environmental stewardship is feeble. Reforms in the water sector still are wanting in that there is duplication of roles and overlapping mandates impacting on water conflict resolution. Water users express confidence in the ability of institutions to resolve conflicts however still accuse them of reluctance to deal with violations of water use rules.

Acknowledgments: I would like to acknowledge Prof. Gideon Nyamasyo, Dr. Kiemo Karatu as my Supervisors, the Water Resources Users Associations in Laikipia County, and Center for Research and Integrated Training in Arid ad Semi Arid Lands Development (CENTRAD) and my family members for their support.

\section{REFERENCES}

Baur, P., Mandeville, N., Lankford, B., Boake, R. (2000). Upstream/downstream competition for water in the Usangu Basin, Tanzania. BHS National Hydrology Symposium.

Bernauer, T., Böhmelt, T. (2020). International conflict and cooperation over freshwater resources. Nat Sustain 3, 350-356.

Bond, J. (2014). A holistic approach to natural resource conflict: The case of Laikipia County, Kenya. Journal of Rural Studies 34, 117-127.

Broadmeadow, S., Nisbet, T.R. (2004). The effects of riparian forest management on the freshwater environment: a literature review of best management practice. Hydrol. Earth Syst. Sci. 8, 286-305.

Chen, W., Olden, J.D. (2017). Designing flows to resolve human and environmental water needs in a dam-regulated river. Nat Commun 8, 2158.

Creswell, J.W., Creswell, J.D. (2018). Research design: Qualitative, quantitative, and mixed method approaches., 18th ed. Sage, Los Angelos.

Daniel, K.A., Barreteau, O. (2015). Water governance across competing scales: couplingland and water management. Journal of Hydrology, Elsevier, 2519 , 2367-2380

Daniell, K.A., Barreteau, O. (2014). Water governance across competing scales: Coupling land and water 
management. Journal of Hydrology 519, 23672380 .

Didier, K.A., Cotterill, A., Douglas-Hamilton, I., Frank, L., Georgiadis, N.J., Graham, M., Ihwagi, F., King, J., Malleret-King, D., Rubenstein, D., Wilkie, D., Woodroffe, R. (2011). Landscape-Scale Conservation Planning of the Ewaso Nyiro: A Model for Land Use Planning in Kenya? Smithsonian Contributions to Zoology 105-123.

Dinar, A., Hogarth, M. (2015). Game Theory and Water Resources Critical Review of its Contributions, Progress and Remaining Challenges. FNT in Microeconomics 11, 1-139.

Faghih, A., Akhavian, R. (2019). A Game-Theory Approach to Construction Dispute Resolution through Mediation. J. Leg. Aff. Dispute Resolut. Eng. Constr. 11, 05019004.

FAO, IWMI. (2018). More people, more food, worse water? a global review of water pollution from agriculture. FAO/IWMI, Rome.

Funder, M., Bustamante, R., Cossio, V., Huong, P.T.M., van Koppen, B. (2012). Strategies of the Poorest in Local Water Conflict and CooperationEvidence from Vietnam, Bolivia and Zambia. Water- alternatives 5, 20-36.

Gichuki, F.N. (2010). Water Scarcity and Conflicts:A Case Study of the Upper Ewaso Ng'iro North Basin.

Government of Kenya GOK. (2010). Constitution of Kenya.

Habiyakare, T., Zhou, N. (2015). Water Resources Conflict Management of Nyabarongo River and Kagera River Watershed in Africa. JWARP 07, 889-896.

Huggins, C. (2000). A comparative Study of Legal Regimes andCommunity Responses to Changing Tenure Patternsin Tanzania and Kenya. Waterfund.

Hui, R., Lund, J.R., Madani, K. (2016). Game theory and risk-based leveed river system planning with noncooperation. Water Resour. Res. 52, 119-134.

Isaboke, E.M. (2015). Influence Of Water Resource Users Associationleadership Competencies On Water Resourcesmanagement: A Case Of Mount Kenya Region. University of Nairobi, Nairobi.

Jhawar, S., Agarwaal, S., Oberoi, T., Sharma, T., Thakkar, A. (2018). Application of game theory in water resource management. nternational Journal of Advance Research and Development 3.

Kenya National Bureau of Statistics (KNBS). (2019). Population and house results. Kenya Bureau of Statistics KNBS, Kenya.

Kiteme, B.P. (2020). Hotspots of Water Scarcity and Conflicts in the Ewaso Ng'iro North Basin: Identifying context-specific water development priorities through an innovative and participatory approach. Centre for Training and Integrated Research in ASAL Development (CETRAD), Nanyuki.

Kiteme, B.P., Gikonyo, J. (2002). Preventing and Resolving Water Use Conflictsin the Mount Kenya Highland-Lowland Systemthrough Water Users' Associations. Mountain Research and Development 22, 332-337.

Kiteme, B.P., Liniger, H., Notter, B., Wiesmann, U., Kohler, T. (2008). Dimensions of Global Change in African Moun-tains: The Example of Mount Kenya.

Kvale, S., Brinkmann, S. (2015). InterViews: learning the craft of qualitative research interviewing, Third edition. ed. Sage Publications, Los Angeles.

Lanari, N., Schuler, R., Kohler, T., Liniger, H. (2018). The Impact of Commercial Horticulture on River Water Resources in the Upper Ewaso Ng'iro River Basin, Kenya. Mountain Research and Development 38, 114-124.

Le Meur, P., Hochet, P., Shem, M., Toure, O. (2006). Groupe de recherche et d'échanges technologiques Conflict over Access to Land \& Water Resources within Sub-Saharan Dry Lands Underlying factors, conflict dynamics and settlement processes. GRETFAO.

MAHLAKENG, K.M. (2015). Environmental Conflicts: The case of the Nile River Basin. University of the Free State, south Africa.

Muigua, K. (2014). Utilizing Africa's Natural Resources to Fight Poverty.

Munia, H., Guillaume, J.H.A., Mirumachi, N., Porkka, M., Wada, Y., Kummu, M. (2016). Water stress in global transboundary river basins: significance of upstream water use on downstream stress. Environ. Res. Lett. 11, 014002.

Nelson, F. (Ed.). (2010). Community rights, conservation and contested land: the politics of 
natural resource governance in Africa. Earthscan, London; Washington, DC.

Okpara, U.T., Stringer, L.C., Dougill, A.J., Bila, M.D. (2015). Conflicts about water in Lake Chad: Are environmental, vulnerability and security issues linked? Progress in Development Studies 15, 308325 .

Opiyo, F.E., Wasonga, O.V., Mureithi, S.M., Schilling, J. (2012). Resource-based conflicts in drought prone-North-western Kenya. Wudpecker Journal Of Agricultural Research 1, 442-453.

Ostrom, E. (2000). Collective Action and the Evolution of Social Norms. Journal of Economic Perspectives 14, 137-158.

Pandey, P. (2011). Understanding Patterns of Water Conflicts: Social and Political Variables. South Asian Survey 18, 157-171.

Petersen-Perlman, J.D., Veilleux, J.C., Wolf, A.T. (2017). International water conflict and cooperation: challenges and opportunities. Water International $42,105-120$.

Rahman, M.A. (2013). Water Security: EthiopiaEgypt Transboundary Challenges over the Nile River Basin. Journal of Asian and African Studies $48,35-46$.

Roe, D., Nelson, F., Sandbrook, C., International Institute for Environment and Development. (2009). Community management of natural resources in Africa: impacts, experiences and future directions. International Institute for Environment and Development, London, UK.

Ross, D. (2019). Game Theory, Winter 2019. ed, The Stanford Encyclopedia of Philosophy. Metaphysics Research Lab, Stanford University, USA.

Shao, W., Cai, J., Liu, J., Luan, Q., Mao, X., Yang, G., Wang, J., Zhang, H., Zhang, J. (2017). Impact of Water Scarcity on the Fenhe River Basin and Mitigation Strategies. Water 9, 30 .

Shrestha, A., Joshi, D., Roth, D. (2020). The hydrosocial dynamics of exclusion and water insecurity of Dalits in peri-urban Kathmandu Valley, Nepal: fluid yet unchanging. Contemporary South Asia 1-16.

Shrestha, A., Roth, D., Joshi, D. (2018). Flows of change: dynamic water rights and water access in peri-urban Kathmandu. E\&S 23, art42.
Swain, A. (2011). Challenges for water sharing in the Nile basin: changing geo-politics and changing climate. Hydrological Sciences Journal 56, 687702.

UNESCO. (2018). The United Nations World Water Development Report 2018: Nature-based Solutions. UNESCO, Paris.

Wang, R.Y., Ng, C.N., Lenzer, J.H., Dang, H., Liu, T., Yao, S. (2017). Unpacking water conflicts: a reinterpretation of coordination problems in China's water-governance system. International Journal of Water Resources Development 33, 553-569.

Warurii, F.K. (2013). Inter-Ethnic Conflicts: Trends, Causes, Effects And Interventions In Rumuruti Division Of Laikipia County, Kenya (1963 -2010). Kenyatta University, Nairobi, Kenya.

Wheeler, K.G., Hall, J.W., Abdo, G.M., Dadson, S.J., Kasprzyk, J.R., Smith, R., Zagona, E.A. (2018). Exploring Cooperative Transboundary River Management Strategies for the Eastern Nile Basin. Water Resour. Res. 54, 9224-9254.

Williams, C. (2011). Research Methods. JBER 5.

Yang, Z.F., Cai, Y.P. (2014). Preface \&quot;Practice and strategies for managing water conflicts between human and ecosystems\&quot; Hydrol. Earth Syst. Sci. $18,3675-3679$.

Zhou, X., Yang, Y., Sheng, Z., Zhang, Y. (2019). Reconstructed natural runoff helps to quantify the relationship between upstream water use and downstream water scarcity in China's river basins. Hydrol. Earth Syst. Sci. 23, 2491-2505. 